\title{
DIRECTORY OF PARASITOLOGISTS
}

\begin{abstract}
Announcement
Electronic communications provide a rapid means of obtaining information from or sending information to colleagues involved in parasitological research. However, there is currently no centralized "directory" that provides the e-mail addresses and FAX numbers of parasitologists. I believe that such a directory would benefit parasitologists, and I am therefore beginning to put together such a directory. I invite all those individuals involved in parasitological research to communicate with me so your names can be included in this new directory.

In addition to e-mail addresses and FAX numbers, this new directory will also include mailing addresses, telephone numbers, research interests, etc. As the directory grows and is updated, it will be sent electronically to everyone whose name appears in it (and who has provided an e-mail address), thus providing parasitologists with the most current information available. For those individuals not currently using electronic mail, I plan to make the directory available on disk at a later date.

Interested readers can contact me via e-mail, and I will forward additional information (a questionnaire) to them. Readers who do not currently have an e-mail address but wish to be included in the directory can contact me via mail or FAX.
\end{abstract}

Peter W. Pappas

The Ohio State University

Department of Zoology

1735 Neil Avenue

Columbus, OH 43210-1293

USA

E-mail: pappas.3@osu.edu

FAX: 614-292-2030 


\title{
(16) \\ SEVENTH INTERNATIONAL TRAINING COURSE ON IDENTIFICATION OF HELMINTH PARASITES OF ECONOMIC IMPORTANCE
}

\author{
4 JULY - 12 AUGUST 1994
}

\section{Who can benefit from the course?}

The course will benefit those engaged in routine identifications of helminth parasites in medical and veterinary laboratories, field work and those involved in training and teaching.

\section{Course contents and aims}

The aim of this applied course is to familiarise participants with up-to-date methods of identification of helminth parasites of economic importance. Identification to genus and species levels will be taught and a large part of the course is devoted to practical work and techniques.

The course is designed to enable participants to identify important helminth parasites rather than to act as further training for research taxonomists.

\section{Course dates}

The course will run over a six week period from 4 July to 12 August 1994.

\section{Admission}

Admission is limited to a maximum of 15 participants and is open to candidates from all countries. Candidates should have a good knowledge of the English language and have some experience of working with helminth parasites. A certificate of attendance will be awarded on completion of the course.

\section{Fees}

A fee of $£ 1,650$ per participant will be charged, payable in advance. This will cover teaching, manual, practical material, administration, etc. It does not include board and lodging which can be secured in St. Albans at extra cost.

\section{Venue}

The course will be held in the laboratories of the International Institute of Parasitology situated in St. Albans, 20 miles $(32 \mathrm{~km})$ to the north of London and readily accessible by rail, car or bus. Accommodation is available in St. Albans.

\section{Further information and application forms may be obtained from:}

Dr. L. M. Gibbons

International Institute of Parasitology

An Institute of CAB INTERNATIONAL

395A Hatfield Road, St. Albans, Herts AL4 0XU, UK

Tel: (0727) 833151 Telex: 9312102254 Fax: (0727) 868721 


\section{Helminthological Abstracts}

Helminthological Abstracts, prepared from the CAB ABSTRACTS database, contains about 5000 records each year selected from journal articles, reports, conferences and books. Each record is in English and includes full bibliographic details and an informative abstract of the original work. Primary literature in over $\mathbf{5 0}$ languages is covered.

This journal is essential reading for anyone whose work relates to the study of parasitic helminths of man and animals

Covers the literature on parasitic helminths, including:

- Gastrointestinal nematodes - Liver flukes - Hydatid - Trichinella - Schistosomes • Filariids • Taenia

Aspects include:

- Morphology - Taxonomy • Immunology • Pathology • Biochemistry • Epidemiology • Life history $\cdot$ Control $\cdot$ Molecular biology

Monthly/annual author and subject indexes.

ISSN: 0957-6789

First issued: 1932 Monthly $€ 272.00$

£204.00* Member country rate

US\$496.00 (Americas only)

Also available on floppy disk

Back issues are available from 1970 with considerable discounts for volumes over 2 years old.

Published by $C A B I$ and available from any of the following addresses:

\section{CAB INTERNATIONAL}

\author{
Headquarters \\ Wallingford \\ Oxon OX10 8DE \\ UK
}

Tel: (0491) 832111

Telex: 847964 (COMAGG G) (602) 6217897

Fax: (0491) 833508

\section{North America}

845 North Park Avenue

Tucson, Arizona 85719

USA

Tel: (800) 5284841

Fax: (602) 6213816
Asia

PO Box 11872

50760 Kuala Lumpur

Malaysia

Tel: (03) 2552922

Telex: 28031 (MA CABI)

Fax: (03) 2551888

\section{Caribbean}

Gordon Street

Curepe

Trinidad and Tobago

Tel: (809) 6624173

Telex: 029424438 (CARIRI)

Fax: (809) 6632859 


\section{Recent Books from CAB INTERNATIONAL}

\section{Textbook \\ Ecology of Marine Parasites (Second Edition)}

$K$ Rohde

This second edition of the main introductory textbook on marine parasites has been revised to take account of recent advances and includes an additional chapter on the structure of marine parasite communities. There are also new sections on pollution, translocations of hosts and parasites, and on the effects of parasites on the aquaculture of marine fish, molluscs and crustacea. The chapters covering ecological, zoogeographical and economic aspects have also been significantly changed.

"Overall, this book is an excellent and stimulating discussion of marine parasites and the roles they play in the sea." Quarterly Review of Biology

Contents: The nature of parasitism / The types of marine parasites / The variety of hosts of marine parasites / Parasites of parasites / General adaptations of parasitic animals / Host-parasite interactions / The ecological niches of parasites / The structure of parasite communities / Characteristics of parasite faunas of different seas / Economic and hygienic importance of marine parasites / Future research

August 1993304 pages Paperback ISBN 0851988458

Price: $€ 19.95$ (US $\$ 38.00$ Americas only)

\section{Human Schistosomiasis}

Edited by $P$ Jordan, G Webbe and R F Sturrock

Essentially a replacement for a previous book, Schistosomiasis: Epidemiology, Treatment and Control (Heinemann, 1982), this book is the standard work on the subject. It includes a completely new chapter on ultrasound, expected to aid identification of early disease in the field and increase our understanding of its evolution. Other chapters, each with an extensive bibliography, review the parasites and their snail intermediate hosts, epidemiology, clinical manifestations and pathology, diagnosis, immunology, drugs and patient management and control.

Contents: The parasites and their life cycles, R F Sturrock/The intermediate hosts and host-parasite relationships, $R$ F Sturrock / Epidemiology, P Jordan and G Webbe / Schistosomes with terminal-spined eggs: Pathological and clinical aspects, Z Farid / Schistosoma mansoni: Pathological and Clinical Aspects, I R Lambertucci / Schistosoma japonicum and S. japonicum-like infections - Epidemiology, clinical and pathological aspects, C Ming Gang / Diagnosis, $H$ Feldmeier / Use of ultrasound, C Hatz / Immunology of schistosomiasis, A E Butterworth / Antischistosomal drugs and clinical practice, A Davis / Control, G Webbe and P Jordan

November 1993480 pages HB ISBN 085198844 X

Price: $€ 65.00$ (US\$123.50 Americas only)

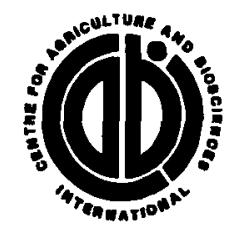

To order, send cheque or credit card payment to:

\section{CAB INTERNATIONAL}

Wallingford, Oxon, OX10 8DE, UK

Tel: (0491) 832111 Fax: (0491) 826090

(Postage free in UK, all other areas please include $£ 1.80 \mathrm{pp}$.) 


\section{NOTES FOR AUTHORS}

The Journal of Helminthology publishes papers on all aspects of helminths, particularly those of medical or veterinary importance. Taxonomic contributions will be acceptable if they contribute to the systematics of a group and particularly if they employ biochemical or molecular biological techniques. Short reviews will also be welcome.

Page Format. The Journal is printed in a two-column format (column width of $80 \mathrm{~mm}$ ) with a text area of $170 \times 225 \mathrm{~mm}$.

Text. Papers should be typed, on one side of the paper only, with double line spacing and ample margins (at least $1.5 \mathrm{~cm}$ ) on each side and with no underlining or bold in text except for scientific names. Draft quality print from a word-processor is not acceptable. Standard abbreviations (e.g. fig. and figs) and metric units must be used.

When the paper has been accepted word-processed text stored on floppy disk is encouraged, providing the software is IBM/DOS compatible, but floppy discs must be accompanied by a hard copy. This will enable papers to be handled rapidly, and with fewer type-setting errors.

Abstract. Each paper must commence with a carefully prepared, accurate, informative abstract, in one paragraph, that is complete in itself and intelligible without reference to text or figures. It should not exceed 250 words. A short title should be provided as a running head.

Tables. Tables should be reduced to the simplest form, and should not be used where text or illustrations give the same information. They should be submitted on separate sheets at the end of the article and must fit conveniently into single column, full width or landscape (if absolutely necessary) format. Table captions should be typed on a separate sheet.

Illustrations. Copies only of artwork should be submitted. The original illustrations should accompany the paper after acceptance and revision. Text figures, line drawings, computer-generated figures and graphs should be of sufficient size and quality to allow for reduction by half or two-thirds. Half-tone photographs are acceptable where they are a real contribution to the text. They should be glossy prints of the same size as they are to appear in the Journal. All figures and letters on photographs must be inserted by the author. Figure and captions should be typed on a separate sheet.

Voucher specimens. The deposition of voucher specimens should be considered where appropriate.

References. References must be based on the name and year system, give full journal titles and conform to the following styles:

Grønvold, J., Wolstrup, J., Larsen, M., Henriksen, S.A. \& Nansen, P. (1993) Biological control of Ostertagia ostertagi by feeding selected nematode-trapping fungi to calves. Цournal of Helminthology 67, 31-36.

Grove, D.I. (1990) A history of human helminthology. 850 pp. Wallingford, CAB International.

Southgate, V.R. \& Rollinson, D. (1987) Natural history of transmission and schistosome interactions. pp. 347-378 in Rollinson, D. \& Simpson, A.J.G. (Eds) The biology of schistosomes: from genes to latrines. London, Academic Press.

Citation of authors in the text should appear in the form: Polaszek (1990) or (Polaszek, 1990). More than one author should be cited in chronological order as: (Holloway et al., 1987; Walker \& Huddleston, 1988).

Offprints. 50 copies of each paper are provided free to the author (or major author) of each paper. Further copies may be obtained on payment, and the number required should be specified and ordered at proof stage.

Manuscripts. Three copies of the manuscript, which must be in English or French (with an English summary) should be accompanied by a letter signed by all the authors and together with artwork submitted to:

The Editor

Journal of Helminthology

International Institute of Parasitology

395A Hatfield Road

St Albans, Herts

AL4 OXU, UK. 


\section{Journal of Helminthology}

Editorial

Review Article

Taylor, M.J. Onchocerca voloulus infections in chimpanzees: an assessment of the requirements for vaccination trials

Research Papers

Agatsuma, T., Yang, L., Kim, D. \& Yonekawa, H. Mitochondrial DNA differentiation of Japanese diploid and triploid Paragonimus westermani

Ando, K., Sato, Y., Miura, K., Matsuoka, H. \& Chinzei, Y. Migration and development of the larvae of Gnathostoma nipponicum in the rat, second intermediate or paratenic host, and the weasel, definitive host.

Dettman, C.D. \& Higgins-Opitz, S.B. The infection characteristics of the antelope schistosomes, Schistosoma margrebowiei and S. leiperi, in inbred BALB/c mice and in Mastomys coucha.

Faliex, E. \& Morand, S. Population dynamics of the metacercarial stage of the bucephalid trematode, Labratrema minimus (Stossich, 1887) from Salses-Leucate lagoon (France) during the cercarial shedding period

Fan, P.C., Lu H. \& Lin, L.H. Experimental transfer of Paragonimus westermani from rodents to rodents following subcutaneous and intraperitoneal routes

Furth, M., Hoida, G., Nahmias, J., Greenberg, Z., Barzilay, A., Goldsmith, R.S. \& El-On, J. The development of new foci of echinococcosis in northern Israel: prevalence in domestic animals

Madhavi, R. \& Jhansilakshmibai, K. The miracidium of Transversotrema patialense (Soparkar, 1924)

Petkevičiūtè, R. \& Regel, K.V. Karyometrical analysis of Microsomacanthus spasskii and M. spiralibursata

Power, J.D., Harnett, W. \& Jenkins, T. Characterization of the surface polypeptides of Strongyloides ratti: a comparison of homogonic and heterogonic strains

Rondelaud, D. Fasciola hepatica: the infection rate and the development of redial generations in Lymnaea truncatula exposed to miracidia after experimental desiccation and activation in water.

Śpakulová, M. Králová, I. \& Cutillas, C. Studies on the karyotype and gametogenesis in Trichuris muris

Stoitsova, S.R. \& Gorchilova, L.N. Effects of luxabendazole on the tegument of Fasciola hepatica ...

Research Notes

Andrews, S.J. \& James, F.M. Further evaluation of a perfusion technique for the recovery of Dictyocaulus viviparus from bovine lungs.

Ito, A., Fan, P.C., Chung, W.C. \& Suzuki, M. Cross protection against Taenia taeniaeformis in rats vaccinated with non-viable oncospheres of Asian Taenia or $T$. saginata.

Lima, W.S., Guimaraes, M.P. \& Lemos, I.S. Occurrence of Angiostrongylus vasorum in the lungs of the Brazilian fox Dusicyon vetulus

Sun, S., Xu, W., He, N. \& Sugane, K. An antigenic recombinant fusion protein from Trichinella spiralis induces a protective response in BALB/c mice

C) CAB INTERNATIONAL, 1994

All rights reserved. No part of this publication may be reproduced, in any form or by any means, electronically, mechanically, by photocopying, recording or otherwise, without prior permission of the copyright owner. 